交献紹等

20. 紡

667.3.022.2

[333] KIPA 式短工程紡綪法 [Wegener, Walther, Mell. Textilber., 1953-5, Vol. 34, Nr. 5, p. 409 412, 図 7, 表 5]，梳毛紀績に打ける工程数の 短縮は雷要な課題であるが，著者は大陸式梳毛紡績の 前紡工程数の短縮にかなりの成功を収めた。 KEPA方 式执よ゙それに使用される機械の構造機能の紹介を し，種くの興味ある紡績データをあげている。この方 式の根幹をなす KEPA ハイドラフト・ドローイング ボックス譜通のボーキュパインローラの代りに周囲 にのこ邓を植えた直径 $160 \mathrm{~mm}$ のシリンダを用い，乙
の上半部に荻するようにバンドを設置し，てれらの適 当な調整によって各䅜の羊毛，あるいは年毛とスフと の混紡スライバを通常 12〜18, 最大 24 倍のバイドラ フトで紡績できる。また KEPA ハイドラフト精紡機

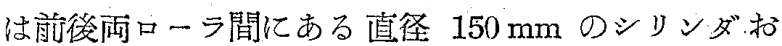
よびてれに接するエプロシバンドとによって繊維岩確 集代把持し，通常 24〜30 最大 34 倍のドラフトで精 紡できる，その結果 KEPA 方式によれば通常の紡績 法に比し, 前紡工程数, 所要㖶力, 人員ともに約半分 で足り，しかも製品の系は均斎度，強力いずれも少し も忩らないことを述べている。 [石川 章一]

\section{1. 化学}

\section{$621.926: 539.215$}

[334] 粉砕の基磁的展望 [E. L. Piret, Chern. Engg. Progress, 1953-2, Vol. 49, No. 2, p. 55 63 ，図 11]粉砕についての基檚的な研究は少いが，

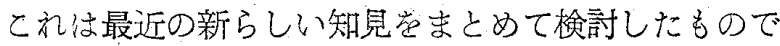
ある。まず粉砕程度を示す方法として比表面䅡法とふ るい分析をのべ，一例として磁鉄鉱は粉势されると比 表面積に比例して抗磁力汃增ずというととを示してい る。るるい分析では結罢の表わしすについていろい万 とのべ，簡晕のために 65\% または $80 \%$ 通逼目をも つて粒度を示すのも一法としてある. 所要エネルギと しては次式をあげている. $\mathrm{P} \times \mathrm{hr} / \mathrm{ton}=\left(0^{\circ} 25 \sim 1^{\circ} 0\right)$ $n^{1 / 4} / \sqrt{P} ， 乙 こ に n は$ 粉砕比(80\%通過目の比)， $P$ は製 品の $80 \%$ 通過目の大きさ (in) で，係数の0\%25はわ らかいもの，1'0 はかたいものに対する值である。ま

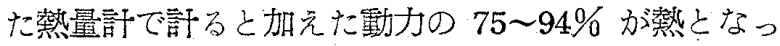
た例もある。エネルギと比表面積は比例するものが多 々，加たさ $(\mathrm{Moh})$ と粉砕抵接 $\left(\mathrm{kg} \cdot \mathrm{cm} / \mathrm{cm}^{2}\right)$ もだいたい 比例する。最捘に基礎的に閴題となる点と共に将来の

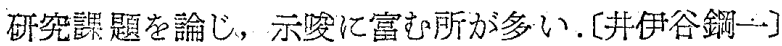

\section{機 峨}

$66.048: 532.529$

[335] フラッシュ蒸発 [R.R.Hughes, H.D.Evans and C. V. Sternling, Chem. Engg. Progress, Vol. 49 , No. 2, $1953-2$, p. $78 \sim 87$, 図 10] 全体的の 解説を行。て後, 加熱炉から蒸発器までの翰送管中の 生成液滴分布や二相流の検討力行われている。蒸発器 は液滴と蒸気を分離するのでサイクロン型をなしてい るが，この内部の流れや分離機構についてはかなりく わしい，特に主流の乱れの影響を論じ，摩摖速度がス トークスの沈降速度にひとしくなるときの液榈粒径を 分離限界径(Kalinske 堡) として紹介しているてとは 興桝ある点である。な拉ストークスの仮定と回転気流 速度の求め方和上び最小分離可能径のみに着目するこ と等に理論上不十分な所があると指苚し，入口面顀が 小さ々，流量が大きくかつ高さが高いてとが分離器と しては望ましいとのべている。てれらはそのままサイ クロンとしての開題であり，表題から推察される熱的 取り扳いはほとんどなく，流れについての検討であ る。

[井伊谷鏑一]

\title{
23.土木機械および鉱山機械
}

$622.233: 622.368(42)$

[336]硬石ころ鉱山用のディーゼル 駆動 Sortfirer 寔 [Engg., 1952, Vol. 173, No. 4498, p. 457 〜 459, 図 4]第一次大戦合成アンモニアを簐需 品の一部として作るために，英国の Billingham に世 界で第 2, 宾国では最大の化学工場が作られた。戦後 その工場住買いとられて合成窒素肥料の生痖開始し た。好都合なととには，之の工場の地下に広大な硬不 こうの理没層があり，てれとアンモニアを反笖させれ 代硫安力作られる、最初はその採掘も小規模であった けれども，工場の登展と共に採揖法も設備も近代化さ れ，その中でも注目す心゙きものは Diesel truck と Joy Loader の使用で，てれによってほとんど地下 $27 \mathrm{~m}$
まで㨄下げうるようになった。更に最近では重直壁岸 採掘するために top-headign と bench 法の代りに可 動性の Shot-firer 車を便用して，それによって幅 $7 \cdot 2$ $\mathrm{m}$ ，高さ $5.4 \mathrm{~m}$ の看直面を爆破できるようになった。 爆破するために約 60 個の穴があけられ，爆薬が詰め られるが，特にこのために生ずる人間の労力と危険を 少くするように設診してある. $34 \mathrm{H}$ の Perkins $\mathrm{P}_{4}$ デ イーゼル機関をもっての車は高さ $3: 3 \mathrm{~m}$, 唇さ $6 \mathrm{~m}$, 幅 $3 \mathrm{~m}$ ，回転移動直径 $7.5 \mathrm{~m}$ をもち，1/3 のこう配文 で安定に上りうる。全体の縤造は Jumbo 起電穖に類 似していて，各部の運動は流体駆動である。

[中原一郎] 